\section{Australian Journal of \\ Crop Science}

AJCS 15(04):570-576 (2021)

doi: 10.21475/ajcs.21.15.04.p2915

\title{
Chemical composition and antifungal potential of essential oils from different aerial parts of Protium ovatum Engl.
}

\author{
Wendel C. de Sousa ${ }^{1}$, Josemar G. Oliveira Filho ${ }^{1}$, Cassia C. F. Alves ${ }^{1}$, Moacir R. Forim ${ }^{2}$, Cristiane \\ de M. Cazal ${ }^{3 *}$
}

\author{
${ }^{1}$ Instituto Federal de Educação, Ciência e Tecnologia Goiano, Rio Verde, GO, Brazil \\ ${ }^{2}$ Departamento de Química, Universidade Federal de São Carlos, São Carlos, SP, Brazil \\ ${ }^{3}$ Instituto Federal de Educação, Instituto Federal de Ciência e Tecnologia Sudeste Minas Gerais, Barbacena, MG, \\ Brazil
}

*Corresponding author: cristiane.cazal@ifsudestemg.edu.br

\begin{abstract}
Protium ovatum is a Brazilian endemic species widely distributed between the Cerrado and Amazon biomes. Here, we evaluate the chemical composition of the essential oils (EO) of different shoot organs from $P$. ovatum including stems, petioles, leaves, flowers, ripe and unripe fruits, and investigate their antifungal potential against Sclerotinea sclerotiorum. The EO were obtained by hydrodistillation in a Clevenger-type apparatus and analysed by GC-MS, followed by PCA analysis. The antifungal activity was performed by agar diffusion. Fruits had the highest essential oil contents among the shoot parts. The constituents were found varyingin the different organs: $\alpha$-Pinene $(0.80-18.3 \%), \beta$-Pinene (0.58-5.17\%), Myrcene (0.52-27.3\%), Limonene (3.15-59.7\%), Caryophyllene E (3.67-16.4\%), Germacrene D (6.34-27.4\%), and $\delta$-Cadinene (2.29-7.63\%). The essential oil from ripe fruit showed the strongest antifungal activity, with the highest Inhibition of Mycelial Growth (IMG) (50.11\%) at the lowest concentration assayed $\left(18.75 \mu \mathrm{g} \cdot \mathrm{mL}^{-1}\right)$. This is the first report on the chemical composition of the essential oils from stems, petioles, flowers, and ripe fruits of $P$. ovatum and their antifungal activity against $S$. sclerotiorum, making it a potential source of antimicrobial agents.
\end{abstract}

Keywords: Protium ovatum; essential oils; stems; petioles; leaves; flowers; fruits; Sclerotinea sclerotiorum.

Abbreviations: EOs_essential oils; URF_unripe fruit; RF_ripe fruit; UniRV_University of Rio Verde; $\mathrm{Na}_{2} \mathrm{SO}_{4}$ anhydrous sodium sulfate; GC_MS/MS_gas chromatography_mass spectrometry; El_electron ionization; IK_Kovats index; PCA_principal components analysis; HCA_hierarchical cluster analysis; PDA_Potato_Dextrose_Agar; IMG_Percentage Inhibition of Mycelial Growth.

\section{Introduction}

The Burceraceae family comprises 17 genera and approximately 750 species distributed throughout the pantropical region. The highest occurrence of the Protieae tribe is recorded in the Neotropical regions around the world (Costa-Lima 2018; Rosalem et al., 2017). This family shares tree or shrub habits and is found on rocky soils such as campos rupestres (open mountaintop vegetation), or more rarely over other species (Costa-Lima 2018). In Brazil, seven genera and 104 species have been reported throughout the country, except in the state of Rio Grande do Sul (BFG, 2015).

The genus Protium is the most widespread in Brazil, and approximately 74 species have already been described. Protium ovatum. Engl. is one of the fourteen endemic species in the country. It is commonly known as "vick-docerrado" and widely distributed between the Cerrado and the Amazon (Castelo et al., 2010; Daly, 2015; Marques et al., 2010; Rosalem et al., 2017). P. ovatum is a shrub 0.4 to 4.0 $\mathrm{m}$ tall, branches glabrous, with few lenticels. Leaves are ovate, glabrous, with petioles $3-5 \mathrm{~cm}$ long. Leaflets are subcoriaceous, shiny, and ovate, with petioles $0.3-1.1 \mathrm{~cm}$ long. Petioles of terminal leaves are larger with possible presence of dark trichomes. Inflorescences are $2.5 \mathrm{~cm}$ long, flowers $6 \mathrm{~mm}$ long, 4-merous,yellow-greenish or greenish color (Lima et al., 2005). This genus is known for its high oleic potential, rich in essential oils and aromatic resins often used in folk medicine (Costa-Lima, 2018).

Studies on the essential oils (EOs) from leaves and unripe fruits of $P$. ovatum have already been reported in the literature by Castelo et al., (2010). Estevam et al. (2017, 2018), also reported the biological potential of EOs from unripe fruits and leaves against Trypanosoma cruzi and Leishmaniasis amazonensis, and cell toxicity in pathogens. Essential oil biosynthesis is sensitive to biotic, abiotic, genetic, physiological, and morphological factors, and may present chemical variation among the plant parts, e.g., stems, petioles, leaves, flowers, fruits, and rhizomes (Barbosa et al., 2017; Tian et al., 2014; Ud-Daula et al., 2016; Zhang et al., 2015).

Essential oils are often used in several industrial processes, including pharmaceuticals, agricultural, food, sanitary, and cosmetics, according to their antibacterial, antifungal, antimycotic, antihelmintic, antiseptic, antispasmodic, antioxidant properties, and their flavour and fragrance features (Mobin et al., 2016; Ud-Daula et al., 2016). EOs have been used as natural antifungal agents in the control of pathogenic fungi such as white mold in vegetables, which is caused by Sclerotinea sclerotiorum (Moraes et al., 2018; 
Valadares et al., 2018). Therefore, the objective of this study was to evaluate the variation in content and chemical composition of Protium ovatum essential oils extracted from different shoot parts (e.g., stems, petioles, leaves, flowers, ripe and unripe fruits), as well as to evaluate its antifungal activity against Sclerotinea sclerotiorum.

\section{Results and Discussion}

Constituents of EO from P. ovatum stems, petioles, leaves, flowers and fruits (ripe and unripe)

The essential oil yield of the different shoot parts of $P$. ovatum is shown in Figure 01. The stems presented the lowest yield $(\% \mathrm{v} / \mathrm{w})$ of essential oil $(0.09 \%)$, below those of petioles $(0.18 \%)$, leaves $(0.24 \%)$, and flowers $(0.23 \%)$. The highest yields were recorded for unripe fruits $(0.45 \%)$ and ripe fruits $(0.48 \%)$, which were significantly different from the other parts.

Similar contents to those of the leaves and fruits of $P$. ovatum obtained in this study were reported by Estevam et al., 2017, 2018, who also collected in the region of Rio VerdeGO. They obtained yields close to $0.30 \%$ for leaves and $0.50 \%$ for unripe fruits. This difference in EO yield between different shoot parts is usually due to biotic and abiotic factors that cause changes in the density of oil glands, secretory cells, modified parenchymal cells, epithelial cells, and lysigenous cavities, or glandular trichomes on plant tissue (Barbosa et al., 2017; Figueiredo et al., 2008; Miguel, 2010; Moghaddam et al., 2015; Morshedloo et al., 2018).

The results showed that the lowest percentage of EOs occurred in the stems of $P$. ovatum. Our findings were similar to those of Origanum vulgare, Etlingera sphaerocephala, Anvilleagarcinii, Seseliannum, and Protium heptaphyllum with yields ranging from 0.1 to $1.3 \%(\mathrm{~m} / \mathrm{m})$ (Khan et al., 2015; Kovacevic et al., 2016; Morshedloo et al., 2018. The low oil yield of $P$. ovatum stems is associated with a lower density of oil trichomes present in the stem tissue (Morshedloo et al., 2018; War et al., 2012).

The chemical composition of the essential oils from the different shoot parts of $P$. ovatum is presented in Table 01 . In total, 51 compounds were identified by mass spectrometry, representing between 99.80 and $99.99 \%$ of the total compounds of the essential oils, consisting mainly of hydrocarbon monoterpenes (10.4-100\%), oxygenated monoterpenes (0-4.84\%), hydrocarbon sesquiterpenes (0$81.0 \%)$, and oxygenated sesquiterpenes (0-12.3\%). A great variation in the chemical profiling of the essential oils from $P$. ovatum was found among the different shoot parts.

The essential oils extracted from the petioles and leaves of $P$. ovatum consisted predominantly of sesquiterpenes, which accounted for $81.4 \%$ and $81.0 \%$ of their total chemical composition, respectively. On the other hand, the essential oils of unripe and ripe fruits showed a chemical profile of monoterpenes, with more than $99.8 \%$ of the total compounds identified in this class. The essential oils of stems and flowers contain mainly monoterpenes and sesquiterpenes, which constitute, more than $82 \%$ of the total compounds identified.

Compounds were identified in the essential oils of stems (30), petioles (27), leaves (20), flowers (23), unripe fruits (8), and ripe fruits (6). Among the constituents common to all shoot parts, $\alpha$-pinene $(0.80-18.3 \%), \beta$-pinene $(0.58-5.17 \%)$, myrcene $(0.52-27.3 \%)$, and limonene (3.15-59.7\%) were most prevalent.
Previous studies on essential oils of $P$. ovatum leaves and fruits confirm the presence of monoterpenic compounds in concentrations similar to those obtained in our study: a low concentration of monoterpenes in the leaves (17.1\%), and a higher concentration in the fruits $(91.4 \%)$ (Estevam et al., 2017, 2018). Similar results have been described for other species of Protium spp. and for different shoot parts, which include resin, leaves, and fruits (Carvalho et al., 2013; Mobin et al., 2016; Mobin et al., 2017; Moraes et al., 2013; Pinto et al., 2010; Pontes et al., 2010, 2007; Siani et al;, 2004; Silva et al., 2016; Silva et al., 2013; Souza et al., 2016; Zoghbi et al., 2005).

\section{Cluster analysis of chemical variation of essential oil}

Results of EO chemical composition for the different organs of $P$. ovatum were classified by the hierarchical cluster analysis (HCA) (Figure 02). A dendrogram was generated from the HCA clustering and the results were separated into four different groups (Figure 02). The first group with the highest similarity comprises the essential oils from unripe and ripe fruits (URF, RF), with similar chemical composition and rich in $\alpha$-pinene ( $15.4 \%$ for URF and $18.3 \%$ for $R F)$, myrcene $(27.3 \%$ for URF and $18.4 \%$ for RF), and limonene ( $41.1 \%$ for URF and $59.7 \%$ for RF). The second group is formed by essential oils from leaves and flowers and has a greater abundance of germacrene D $(21.0 \%$ for URF and $17.5 \%$ for RF) and germacrene A (28.6\% for URF and $21.4 \%$ for RF). The main constituents that separated the third group formed by the essential oils from stems were mainly myrcene (10.9\%), limonene (11.8\%), and caryophyllene $E$ (16.4\%). The fourth group formed by essential oils from petioles showed the largest difference between the various shoot parts and is rich in germacrene $D(27.4 \%)$ and $\alpha$ muurolene (22.8\%).

The results of this study show considerable differences in the chemical composition of essential oils from different shoot parts of $P$. ovatum. This chemical variation in the essential oils may be due to the non-continuous and nonhomogeneous production of secondary metabolites in the different organs and development stages of the plant (Gobbo-Neto et al., 2007; Tian et al., 2014). Chemical variation similar to that observed between different shoot parts of $P$. ovatum has already been reported in other species (Kovacevic et al., 2016; Masoudi et al., 2017; UdDaula et al., 2016).

\section{Antifungal activity of EO of P. ovatum leaves, flowers and ripe fruits}

The evaluation of the antifungal activity of the essential oils from leaves, flowers, and ripe fruits of $P$. ovatum is shown in Figure 3. All EOs inhibited S. sclerotiorum mycelial growth in a dose-dependent manner. The results indicated significant differences in mycelial growth inhibition with the increase in the concentrations of the essential oils.

The stronghest antifungal activity was found for ripe fruit EOs, which had the highest IMG $(50.11 \%)$ at the lowest concentration assayed $\left(18.75 \mu \mathrm{g} \cdot \mathrm{mL}^{-1}\right)$. On the other hand, the leaf EOs had the weakest antifungal activity compared with the other treatments and IMG of $42.23 \%$ at the highest concentration assayed $\left(600 \mu \mathrm{g} \cdot \mathrm{mL}^{-1}\right)$.

In vitro antifungal activity of plant extracts and essential oils of different plant species against $S$. sclerotiorum were 
Table 1. Chemical composition of the essential oil from different shoot organs of Protium ovatum.

\begin{tabular}{|c|c|c|c|c|c|c|c|c|c|}
\hline \multirow{2}{*}{ Compounds } & \multirow{2}{*}{$\mathrm{RT}(\min )$} & \multirow{2}{*}{ Rlexp } & \multirow{2}{*}{ RIlit } & \multicolumn{6}{|c|}{ RA (\%) } \\
\hline & & & & STE & PET & LEA & FLO & URF & RF \\
\hline$\alpha$-thujene & 5.257 & 917 & 924 & 0.22 & - & - & - & 0.44 & - \\
\hline$\alpha$-pinene & 5.433 & 924 & 932 & 2.59 & 0.8 & 3.28 & 3.96 & 15.44 & 18.28 \\
\hline Sabinene & 6.466 & 963 & 969 & 5.96 & - & - & - & 0.48 & 0.27 \\
\hline$\beta$-pinene & 6.583 & 967 & 974 & 0.63 & 0.58 & 1.14 & 0.90 & 5.17 & 2.96 \\
\hline Trans-isolimone & 6.911 & 979 & 980 & - & - & 0.92 & - & - & - \\
\hline Myrcene & 6.920 & 980 & 988 & 10.91 & 0.52 & 1.63 & 2.98 & 27.27 & 18.36 \\
\hline$\delta$-3-carene & 7.566 & 1003 & 1008 & 2.26 & 2.83 & 3.12 & 24.76 & 8.60 & - \\
\hline p-cymene & 8.009 & 1015 & 1020 & 2.06 & - & - & - & - & - \\
\hline o-cymene & 8.014 & 1016 & 1022 & - & - & - & - & - & 0.39 \\
\hline Limonene & 8.144 & 1019 & 1024 & 11.82 & 4.74 & 3.15 & 4.39 & 41.12 & 59.73 \\
\hline$\beta$-ocimene Z & 8.412 & 1027 & 1032 & 1.32 & 0.97 & & 1.83 & 1.36 & - \\
\hline$\beta$-ocimene $\mathrm{E}$ & 8.779 & 1037 & 1044 & - & - & 0.66 & 0.91 & - & - \\
\hline Terpinolene & 10.265 & 1079 & 1086 & 0.88 & - & - & 1.59 & - & - \\
\hline Terpinen-4-ol & 13.801 & 1169 & 1174 & 4.84 & - & - & - & - & - \\
\hline$\alpha$-copaene & 22.062 & 1366 & 1374 & 2.4 & 2.73 & 4.22 & 1.32 & - & - \\
\hline$\beta$-Panasinsene & 22.450 & 1375 & 1381 & 0.28 & - & - & - & - & - \\
\hline$\beta$-cubebene & 22.663 & 1380 & 1387 & 0.2 & 0.36 & - & - & - & - \\
\hline$\beta$-bourbonene & 22.995 & 1388 & 1387 & - & - & 0.43 & 0.72 & - & - \\
\hline Sibirene & 23.214 & 1393 & 1400 & - & - & 0.54 & - & - & - \\
\hline Caryophyllene E & 23.865 & 1409 & 1417 & 16.39 & - & 13.34 & 3.68 & - & - \\
\hline$\beta$-4.8-epoxy- caryophyllene & 24.422 & 1423 & 1423 & - & 7.78 & - & - & - & - \\
\hline ү-elemene & 24.651 & 1428 & 1434 & 0.68 & - & - & - & - & - \\
\hline$\beta$-gurjunene & 24.835 & 1433 & 1431 & 0.42 & - & - & - & - & - \\
\hline Epi- $\beta$-santalene & 25.091 & 1439 & 1445 & 0.52 & - & - & - & - & - \\
\hline$\alpha$-humulene & 25.242 & 1443 & 1452 & 1.16 & 1.32 & 1.76 & 0.92 & - & - \\
\hline Cis-3.5-diene- muurola & 25.380 & 1446 & 1448 & - & 1.07 & - & 0.23 & - & - \\
\hline Allo-aromadendrene & 25.554 & 1451 & 1458 & 0.24 & - & - & - & - & - \\
\hline p-muurolene & 26.356 & 1471 & 1478 & 7.19 & - & - & - & - & - \\
\hline$\beta$-acoradiene & 26.639 & 1478 & 1469 & - & 0,58 & - & - & - & - \\
\hline Germacrene D & 26.997 & 1486 & 1484 & 6.34 & 27.38 & 21.04 & 17.51 & - & - \\
\hline$\alpha$-muurolene & 27.554 & 1500 & 1500 & - & 22.84 & - & - & - & - \\
\hline Germacrene A & 27.563 & 1500 & 1508 & - & - & 28.59 & 21.43 & - & - \\
\hline Cubebol & 27.686 & 1504 & 1514 & 0.18 & 1.48 & - & - & - & - \\
\hline$\gamma$-cadinene & 27.695 & 1504 & 1513 & - & 0,7 & - & - & - & - \\
\hline$\alpha$-bulnesene & 27.706 & 1504 & 1509 & - & - & - & 0.86 & - & - \\
\hline$\delta$-amorphene & 27.977 & 1511 & 1511 & - & 1.55 & - & - & - & - \\
\hline$\delta$-cadinene & 28.049 & 1.513 & 1522 & 7.14 & 6.64 & 7.63 & 2.29 & - & - \\
\hline -bisabolene $\mathrm{E}$ & 28.804 & 1533 & 1529 & 1.23 & 0.81 & - & - & - & - \\
\hline $\begin{array}{l}\text { cis-sesquisabinenehydrate (IPP } \\
\text { vs. } \mathrm{OH} \text { ) }\end{array}$ & 29.332 & 1546 & 1542 & - & 1.02 & - & - & - & - \\
\hline Trans-dauca-4(11).7-diene & 29.909 & 1561 & 1556 & - & 5.34 & - & - & - & - \\
\hline Germacrene B & 29.922 & 1562 & 1559 & - & - & 3.42 & 1.62 & - & - \\
\hline Spathulenol & 30.147 & 1567 & 1577 & 5.29 & 1.82 & 3.09 & 4.17 & - & - \\
\hline Caryophyllene Oxide & 30.371 & 1573 & 1582 & 3.21 & 1.53 & 1.12 & - & - & - \\
\hline Viridiflorol & 30.954 & 1588 & 1592 & - & - & - & 1.87 & - & - \\
\hline Globulol & 31.142 & 1593 & 1590 & 0.67 & - & - & 1.12 & - & - \\
\hline$\alpha$-epi-cadinol & 32.515 & 1630 & 1638 & 1.89 & - & - & 0,19 & - & - \\
\hline$\alpha$-epia-muurolol & 33.076 & 1645 & 1640 & - & 2,14 & - & - & - & - \\
\hline$\alpha$-muurolol (=Torreyol) & 33.300 & 1651 & 1644 & - & 0,2 & - & - & - & - \\
\hline$\alpha$-cadinol & 33.594 & 1659 & 1652 & - & 0,83 & 0,37 & 0,97 & - & - \\
\hline$\alpha$-epi-bisabolol & 34.111 & 1673 & 1683 & 1.08 & - & 0,55 & - & - & - \\
\hline Nerolidylisobutyrate Z & 34.629 & 1787 & 1784 & - & 1,24 & - & - & - & - \\
\hline Hydrocarbon monoterpenes & & & & 38.65 & 10.44 & 13.9 & 41.32 & 99,88 & 99,99 \\
\hline Oxygenated monoterpenes & & & & 4.84 & - & - & - & - & - \\
\hline Hydrocarbon sesquiterpenes & & & & 44.18 & 81.36 & 80.97 & 50.47 & - & - \\
\hline Oxygenated sesquiterpenes & & & & 12.32 & 8 & 5,12 & 8,12 & - & - \\
\hline Total identified & & & & 99.99 & 99.8 & 99,99 & 99,91 & 99,88 & 99,99 \\
\hline
\end{tabular}




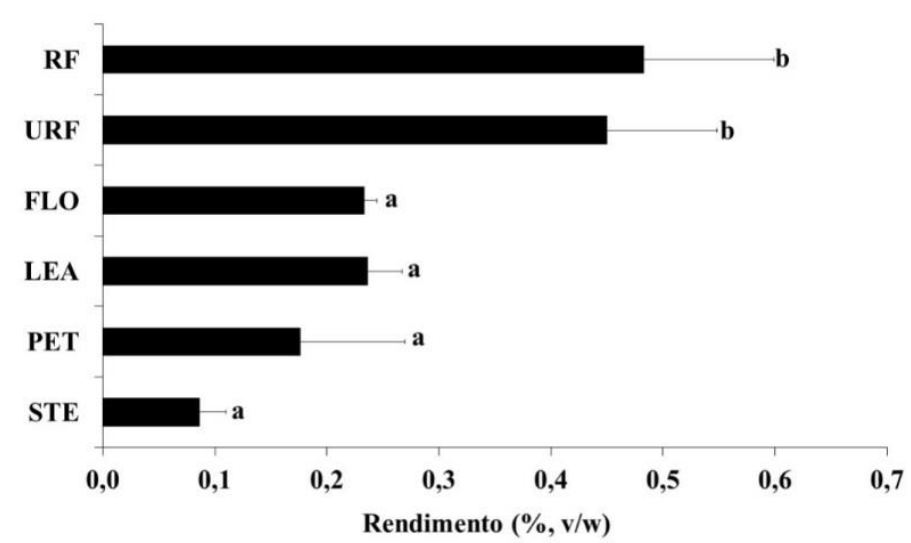

Fig 1. Essential oil yield $(\%, v / m)$ of different shoot parts of Protium ovatum. STE: Stems; PET: Petioles; LEA: Leaves; FLO: Flowers; URF: Unripe Fruits; RF: Ripe Fruits. Bars followed by the same letter are not significantly different.

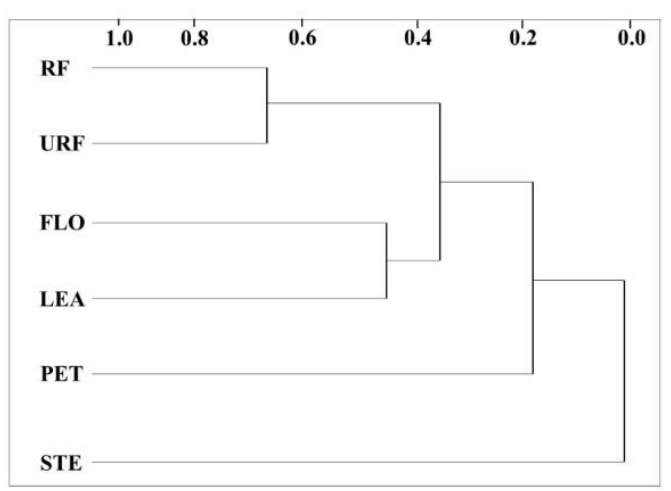

Fig 2. Dendrogram of the hierarchical cluster analysis (HCA) of the chemical similarity between the essential oils from different shoot parts of $P$. ovatum collected in July 2017. RF: Ripe Fruits; URF: Unripe Fruits; FLO: Flowers; LEA: Leaves; STE: Stems; PET: Petioles.

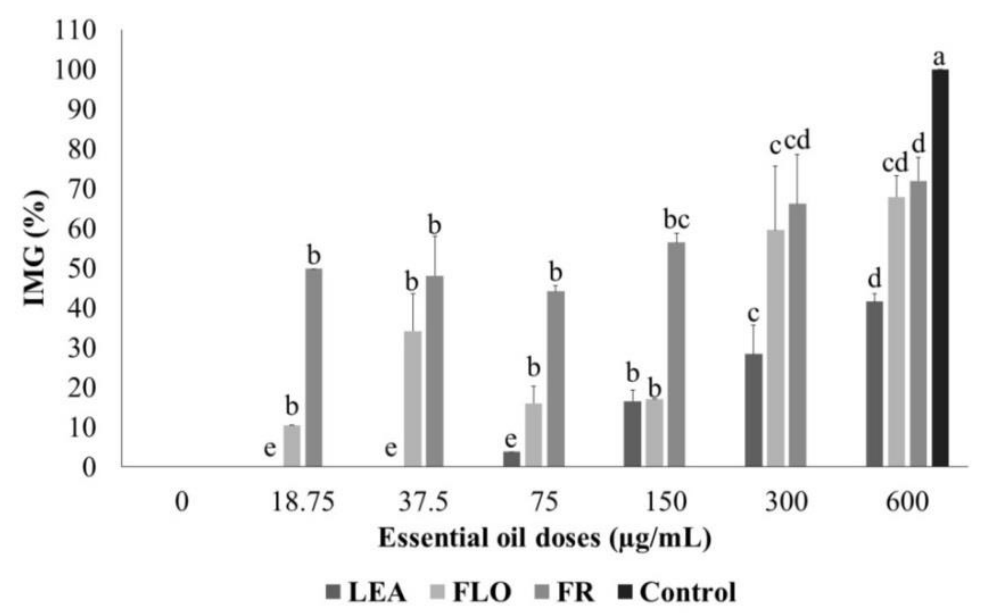

Fig 3. Percentage inhibition of mycelial growth (IMG), by the essential oils from leaves, flowers, and fruits of Protium ovatum against the fungus Sclerotinia sclerotiorum. LEA: Leaves; FLO: Flowers; RF: Ripe fruits. Bars with different letters represent significant difference for the concentration $(p<0.05)$ between treatments and controls.

already reported (Moraes et al., 2018; Silva et al., 2018; Valadares et al., 2018).

Ours results indicated considerable antifungal activity of EOs from leaves, flowers, and ripe fruits of $P$. ovatum. The antifungal activity of $P$. ovatum EOs against pathogenic plant fungi is reported in the literature. In this study, the EOs of ripe fruits showed the highest inhibitory activity against $S$. sclerotiorum compared with the other oils studied. According to Burt (2004) and Negi (2012), several factors, including chemical structure, bioactive compound, essential oil concentration, and type of microorganism play important roles in essential oil efficiency. Table 01 shows the different chemical profiles of the EOs. Limonene represents $59.38 \%$ of the EO compounds in ripe fruits, $4.39 \%$ in flowers, and $3.15 \%$ in leaves, with a very strong antifungal property effective against fungi that cause food spoilage (Cheng et al., 2006). Limonene also has an effective antibacterial property against pathogenic bacteria (Alonso-Gutierrez et al., 2013). The highest EO activity of the ripe fruit may be related to its higher limonene concentration compared with the other oils studied. 


\section{Materials and Methods}

\section{Plant material}

The plant material was collected from as ingle population of $P$. ovatum in an area of Cerrado belonging to the University of Rio Verde (UniRV), Rio Verde, Goiás, Brazil (1747'15.0"S $50^{\circ} 57^{\prime} 59.9^{\prime \prime} \mathrm{W}, 839 \mathrm{~m}$ altitude). The shoot system parts (stems, flowers, petioles, and leaves) were collected at the plant flowering stage in June 2017. Fruits were collected between August (unripe fruits) and September (ripe fruits), in 2017. Voucher specimens of the botanical material were deposited in the Herbarium of the Federal Institute of Education, Science and Technology - Campus Rio Verde, and assigned the collection number 628 .

\section{Extraction of EO}

Essential oils of different parts of $P$. ovatum were extracted from fresh matter collected between 7 a.m. and 10 a.m. After collection, the plant was separated between different organs: stems from petioles, petioles from leaf, and ripe from unripe fruits. Then, each plant part was weighed (100 $\mathrm{g})$, soaked in $500 \mathrm{~mL}$ of ultrapure water, and subjected to hydrodistillation extraction using a Clevenger-type apparatus, at $70{ }^{\circ} \mathrm{C}$ for $3 \mathrm{~h}$. The EO obtained was dried using $3.0 \mathrm{~g}$ of anhydrous sodium sulfate $\left(\mathrm{Na}_{2} \mathrm{SO}_{4}\right)$, filtered, and stored in a glass vial protected from light, sealed, and kept at an average temperature of $4{ }^{\circ} \mathrm{C}$ for further analysis. EO extraction was performed for each $P$. ovatum organ in triplicate $(n=3)$.

The average EO yield (\%) was calculated based on fresh plant matter according to Zhang et al. (2015).

\section{Analysis of EO}

The analysis of the chemical profile of $P$. ovatum essential oils was performed on a gas chromatograph coupled to a sequential mass spectrometer (CG-MS/MS) equipped with a Combi PAL AOC-5000 automatic sample injector, a Restek RTx-5MS fused silica capillary column $(30 \mathrm{~m} \times 0.250 \mathrm{~mm} \times$ $0.250 \mu \mathrm{m}$ ), and a Sequential Mass Spectrometer (MSTQ8040 Shimadzu). Mass spectra data were recorded in electron ionization mode (EI) at $70 \mathrm{eV}$. The initial column temperature was programmed at $60^{\circ} \mathrm{C}$ for 3 minand riseto $200{ }^{\circ} \mathrm{C}$ at $3^{\circ} \mathrm{Cmin}^{-1}$, riseto $280^{\circ} \mathrm{C}$ at $15^{\circ} \mathrm{C} \cdot \mathrm{min}^{-1}$ and hold for 1 min. The injector temperature was $230^{\circ} \mathrm{Cand}$ the detector temperature was $300^{\circ} \mathrm{C}$. Helium was used as carrier gas with injection pressure of $57.4 \mathrm{KPa}$, in the splitless mode: 150, mass detection rangefrom 43 to $550 \mathrm{Da}$, and flow rate of 3 $\mathrm{mL} \cdot \mathrm{min}^{-1}$. Identification of oil components was based on the linear retention index (Kovats index - IK) related to retention times of a homologous series of $n$-alkanes $\left(C_{7}\right.$ to $\left.C_{40}\right)$ and the observed fragmentation pattern in mass spectra, comparing with the literature (ADAMS, 2007) and the Nist ${ }^{\circledR} 11$ mass spectral library.

\section{PCA analysis of the chemical variation in essential oil composition}

Principal component analysis (PCA) was applied to evaluate the interrelationships between the chemical constituents of the essential oils from different $P$. ovatum parts using the software Pirouette ${ }^{\circledR} 4.0$ (Infometrix Inc., Bothell, WA, USA). Hierarchical cluster analysis (HCA) was used to evaluate the similarity between the samples according to component distribution and hierarchical grouping was performed according to the Ward's minimum variance criterion (Ward, 1963).

\section{Anti-sclerotinia assay}

The biological assay was performed at the Plant Microbiology Laboratory of the Goiás Federal Institute - Rio Verde Campus. The phytopathogenic fungus Sclerotinia sclerotiorum Ss12 (BRM 29673) was kindly provided by Embrapa Rice and Beans Research Center, Santo Antônio de Goiás, GO. Initially, essential oils of leaves and fruits of $P$. ovatum were prepared in emulsion [water and $0.05 \%$ Tween $\left.{ }^{\circledR} 80(\mathrm{~m} / \mathrm{v})\right]$ in different concentrations $(18.75,37.5$, $75,150,300$, and $\left.600 \mu \mathrm{g} \cdot \mathrm{mL}^{-1}\right)$. Aliquotes of $100 \mu \mathrm{L}$ of each oil concentration was spread over all the surface of plates containing sterilized and solidified Potato-Dextrose-Agar (PDA) culture medium, using a sterilized Drigalski loop. After seven days of fungal culture, a $S$. sclerotiorum mycelial disc was placed in the center of the plate (BALBI-PEÑA et al., 2006; SILVA et al., 2009). Mycelial radial growth of colonies was measured daily, starting from $24 \mathrm{~h}$ after the inoculation until the complete growth of colonies in the control treatment.

The antifungal activity was measured by both the mean of mycelial growth inhibition of fungus treated with the essential oils and the controls. Sterile distilled water was used as negative control and the fungicide fluazinam as Frowncide $500 \mathrm{SC}\left(10 \mu \mathrm{g} \cdot \mathrm{mL}^{-1}\right.$ active ingredient) was used as a positive control. Tween $80[0.05 \%(\mathrm{w} / \mathrm{v})]$ was used as adjuvant for homogenization of the essential oils in water. The antifungal activity was calculated by the Percentage Inhibition of Mycelial Growth (IMG), according to the equation:

$\operatorname{IMG}(\%)=\frac{\text { (Control growth- Treatment growth) }}{\text { Control growth }} \times 100$ as described by Venturoso et al. (2011) and Andrade et al. (2018).

The results of this study were analysed by analysis of variance and the means were compared by the Tukey's test at $5 \%$ of probability, using the statistical software BioEstat version 5.0 .

\section{Conclusion}

The results of this work show that the content and chemical composition of Protium ovatum essential oils varied according to the different shoot organs. This study has also confirmed the antifungal potential of these essential oils against Sclerotinea sclerotiorum, and showed that the essential oils of ripe fruits have the highest cytotoxic activity, making it a natural source of antimicrobial compounds forutilization by the food and agricultural industry.

\section{Disclosure statement}

The authors declare no conflict of interest.

\section{Acknowledgements}

The authors thank to FAPEG, FAPEMIG, CNPq, CAPES, IF GOIANO and IF SUDESTE MG for their financial support.

\section{References}

Adams RP (2007) In Identification of Essential Oil Components by Gas Chromatography/Quadrupole Mass Spectrometry, Allured Publishing Corporation: Carol Stream. $469 p$.

Alonso-Gutierrez J, Chan R, Batth TS, Adams PD, Keasling JD, Petzold CJ, Lee TS (2013) Metabolic engineering of 
Escherichia coli for limonene and perillyl alcohol production. Metab Eng. 19, 33-41.

Andrade BS, Matias R, Corrêa BO, Oliveira AKM, Guidolin DGF, Roel AR (2018) Phytochemistry, antioxidant potential and antifungal of Byrsonima crassifolia on soil phytopathogen control. Braz J Bio. 78(1): 140-146.

Barbosa R, Cruz-Mendes Y, Silva-Alves KS, Ferreira-Da-Silva FW, Ribeiro NM, Morais LP, Leal-Cardoso JH (2017) Effects of Lippia sidoides essential oil, thymol, p-cymene, myrcene and caryophyllene on rat sciatic nerve excitability. Braz J Med Biol Res. 50(12):1-6.

Balbi-Peña MI, Becker A, Stangarlin JR, Franzener G, Lopes MC, Schwan-Estrada KRF (2006) Controle de Alternaria solani em tomateiro por extratos de Curcuma longa e Curcumina - I. Avaliação in vitro. Fitopatol Bras. 31(3): 37.

BFG (2015) Growing knowledge: An overview of seed plant diversity in Brazil. Rodriguesia. 66(4): 1085-1113.

Burt S (2004) Essential oils: their antibacterial properties and potential applications in foods-a review. Int J Food Microbiol. 94(3): 223-253.

Carvalho LE, Magalhães LAM, Lima MP, Marques MOM, Facanali R (2013) Essential Oils of Protium of the Adolpho Ducke Forest Reserve: Protium crassipetalum, $P$. heptaphyllum subs. ulei, $P$. pilosissimum and $P$. polybotryum. J Essent Oil Bear PI. 16(4): 551-554.

Castelo AVM, Del Menezzi CHS, Resck IS (2010) Yield and spectroscopic analysis (1H, 13C NMR; IR) of essential oils from four plants of the Brazilian Savannah. Cerne. 16(4): 573-584.

Cheng Z, Moore J, YU L (2006) High-Throughput Relative DPPH Radical Scavenging Capacity Assay. J Agr Food Chem. 54(20), 7429-7436.

Costa-Lima JL (2018) Flora das cangas da serra dos carajás, pará, brasil: Rhizophoraceae. Rodriguesia. 69(1): 205-207.

Estevam EBB, Alves CCF, Esperandim VR, Cazal CM, Souza AF, Miranda MLD (2018) Chemical composition, antiTrypanosoma cruzi and cytotoxic activities of the essential oil from green fruits of Protium ovatum (BURSERACEAE). Rev Bras Frutic. 40(1).

Estevam EBB, Deus IPB, Silva VP, Silva EAJ, Alves CCF, Alves JM, Caza CM, Magalhães LG, Pagotti MC, Esperandim VR, Souza A,Miranda MLD (2017) In vitro antiparasitic activity and chemical composition of the essential oil from Protium ovatum leaves (Burceraceae). An Acad Bras Cienc. 89(4): 3005-3013.

Figueiredo AC, Barroso JG, Pedro LG, Scheffer JJC (2008) Factors affecting secondary metabolite production in plants: volatile components and essential oils. Flavour Frag J. 23(4): 213-226.

Gobbo-neto L, Lopes NP (2007) Plantas medicinais: fatores de influência no conteúdo de metabólitos secundários. Quim Nova. 30(2): 374-381.

Khan M, Abdullah MMS, Mousa AA, AlkhathlanHZ (2015) Chemical composition of vegetative parts and flowers essential oils of wild Anvillea garcinii grown in Saudi Arabia. Rec Nat Prod. 10(2): 251-256.

Kovacevic NN, Marcetic MD, Lakusic DV, Lakusic BS (2016) Composition of the essential oils of different parts of Seseli annuum L. (Apiaceae). J Essent Oil Bear PI. 19(3): 671-677.

Lima LR, Pirani JR (2005) Burseraceae. Flora Fanerogâmica do Estado de São Paulo, 4: 163-168.
Marques DD, Sartori RA, Lemos TLG, Machado LL, Souza JSN, MonteFJQ (2010) Chemical composition of the essential oils from two subspecies of Protium heptaphyllum. Acta Amazon. 40(1), 227-230.

Masoudi S, Kakavand S (2017) Volatile constituents of the aerial parts of Terataenium lasiopentalum (boiss.) Manden., stems and leaves of Dorema ammoniacum d.don. And leaves, fruits and stems of Leutea petiolare (DC.) M. pimen from Iran. J Chil Chem Soc. 62(1): 33113314.

Miguel MG (2010) Antioxidant and anti-inflammatory activities of essential oils: A short review. Molecules. 15(12): 9252-9287.

Mobin M, Lima SG, Almeida LTG, Takahashi JP, Teles JB, Szeszs MW, Martins MA, Carvalho AA, Melhem MDC (2016) MDGC-MS analysis of essential oils from Protium heptaphyllum (Aubl.) and their antifungal activity against Candida specie. Rev Bras PI Med. 18(2): 531-538.

Mobin M, Lima SG, Almeida LTG, Silva Filho JC, Rocha MS, Oliveira AP, Mendes MB, Carvalho FAA, Melhem MSC, Costa JGM (2017) Gas chromatography-triple quadrupole mass spectrometry analysis and vasorelaxant effect of essential oil from Protium heptaphyllum (Aubl.) March. Biomed Res Int. 2017.

Moghaddam M, Miran SNK, Pirbalouti AG, Mehdizadeh L, GhaderiY (2015) Variation in essential oil composition and antioxidant activity of cumin (Cuminum cyminum L.) fruits during stages of maturity. Ind Crop Prod. 70, 163-169.

Moraes MM, Camara CAG, Ramos CS (2013). Seasonal variation in the essential oil of Protium bahianum Daly (Burseraceae). J Essent Oil Bear PI. 16(3): 300-307.

Morshedloo MR, Mumivand H, Craker LE, Maggi F (2018) Chemical composition and antioxidant activity of essential oils in Origanum vulgare subsp. gracile at different phenological stages and plant parts. J Food Process Pres. 42(2): 1-8.

Negi PS (2012) Plant extracts for the control of bacterial growth: Efficacy, stability and safety issues for food application. Int J Food Microbiol. 156(1): 7-17.

Moraes SPCB, Moraes WB, Moraes WB, Camara GR, Maciel KS, Lima PAM, Ferreira A, Alexandre RS, Lopes JC (2018) Cinnamon and citronella essential oils in the in vitro control of the fungi Aspergillus sp. and Sclerotinia sclerotiorum. Afr J Agric Res. 13(35): 1811-1815.

Pinto DS, Carvalho LE, Lima MP, Marques MOM, Facanali R, Ribeiro JELS (2010) Volatiles of foliar rachis, branches and resin elicited by insects from Protium hebetatum grows wild in Amazon. J Essent Oil Bear PI. 13(6): 699-703.

Pontes WJT, Oliveira JCG, Câmara CAG, Lopes ACHR, Gondim Júnior MGC, Oliveira JV, Barros R, Schwartz MOE (2007) Chemical composition and acaricidal activity of the leaf and fruit essential oils of Protium heptaphyllum (Aubl.) Marchand (Burseraceae). Acta Amazon. 37(1): 103-109.

Pontes WJT, Silva JMO, Camara CAG, Gondim-Júnior MGC, Oliveira JV, Schwartz MOE (2010) Chemical composition and acaricidal activity of the essential oils from fruits and leaves of Protium bahianum daly. J Essent Oil Res. 22(3): 279-282.

Rosalem PF, Picão TB, Rodrigues-Lisoni FC, Martins AR (2017) Leaf anatomy of Protium ovatum and its antiproliferative potential in cervical cells. Rev Bras Farmacogn. 27(6): 673-678.

Siani AC, Garrido IS, Monteiro SS, Carvalho ES, Ramos MFS (2004) Protium icicariba as a source of volatile essences. Biochem Syst Ecol. 32(5): 477-489. 
Silva AC, Sales NLP, Araújo AV, Júnior CFC (2009) Efeito in vitro de compostos de plantas sobre o fungo Colletotrichum gloeosporioides Penz. Isolado do maracujazeiro. Cienc Agrotec. 33(1):1853-1860.

Silva ER, Oliveira DR, Melo MFF, Bizzo HR, Leitão SG (2016) Report on the Malungo expedition to the Erepecuru river, Oriximiná, Brazil. Part I: Is there a difference between black and white breu? Rev Bras Farmacogn. 26(5): 647656.

Silva ER, Oliveira DR, LeitãoSG, Assis IM, Veiga-Junior VF, Lourenço MC, Alviano DS, Alviano CS,Bizzo HR (2013) Essential oils of Protium spp. samples from Amazonian popular markets: Chemical composition, physicochemical parameters and antimicrobial activity. J Essent Oil Res. 25(3): 171-178.

Silva EAJ, Silva VP, Alves CCF, Alves JM, Souchie EL, Barbosa LCA (2018) Chemical composition of the essential oil of Psidium guajava leaves and its toxicity against Sclerotinia sclerotiorum. Semina: Cienc Agrár. 39(2): 865-874.

Souza LR, Trindade FG, Oliveira RA, Costa LCB, Gomes VM, Cunha M (2016) Histochemical characterization of secretory ducts and essential oil analysis of Protium species (Burseraceae). J Essent Oil Res. 28(2): 166-171.

Tian J, Zeng X, Zhang S, Wang Y, Zhang P, Lü A, Peng X (2014) Regional variation in components and antioxidant and antifungal activities of Perilla frutescens essential oils in China. Ind Crop Prod. 59: 69-79.
Ud-Daula AFMS, Demirci F, Abu Salim K, Demirci B, Lim LBL, Baser KHC, Ahmad N (2016) Chemical composition, antioxidant and antimicrobial activities of essential oils from leaves, aerial stems, basal stems, and rhizomes of Etlingera fimbriobracteata (K.Schum.) R.M.Sm. Ind Crop Prod. 84: 189-198.

Valadares ACF, Alves CCF, Alves JM, Deus IPBD, Filho, JGDEO, Caroline T, Santos LDOS (2018) Essential oils from Piper aduncum inflorescences and leaves: chemical composition and antifungal activity against Sclerotinia sclerotiorum. An Acad Bras Cienc. 90: 2691-2699.

Venturoso LR, Bacchi LMA, Gavassoni WL, Conus LA, Pontim BCA, Bergamin AC (2011) Atividade antifúngica de extratos vegetais sobre o desenvolvimento de fitopatógenos. Summa Phytopathologica. 37(1): 18-23.

War AR, Paulraj MG, Ahmad T, Buhroo AA, Hussain B, Ignacimuthu S, Sharma HC (2012) Mechanisms of plant defense against insect herbivores. Plant Signal Behav. 7(10): 1306-1320.

Ward JH (1963) Hierarchical grouping to optimize an objective function. J Am Stat Assoc. 58(301): 236-44.

Zhang DY, Yao XH, Duan MH, Wei FY, Wu GH, Li L (2015) Variation of essential oil content and antioxidant activity of Lonicera species in different sites of China. Ind Crop Prod. 77: 772-779.

Zoghbi MGB, Andrade EHA, Lima MP, Silva TMD, Daly DC (2005) The essential oils of five species of Protium growing in the North of Brazil. J Essent Oil Bear PI. 8(3): 312-317. 